\title{
Carbon Partitioning and Translocation in Primocane-fruiting Red Raspberries (Rubus idaeus L.)
}

\author{
Jean-Pierre Privé1, J.A. Sullivan, and J.T.A. Proctor \\ Department of Horticultural Science, University of Guelph, Guelph, Ont., N1G 2W1 Canada
}

\begin{abstract}
Additional index words. autumn-bearing, fall-bearing, photosynthesis, ${ }^{14} \mathrm{C}$, leaf removal, girdling
Abstract. Leaf removal, cane girdling, and ${ }^{14} \mathrm{C}$ translocation patterns were used to study source-sink relationships of primocane-fruiting (PF) red raspberries. Although the leaves in the reproductive zone were most important for vegetative and reproductive development, compensatory effects between the cane leaves were evident. When ${ }^{14} \mathrm{C}$ translocation was studied in the reproductive portion of the cane, the lateral closest to the ${ }^{14} \mathrm{C}$-treated leaf was the major sink for carbohydrate from that leaf, independent of leaf position or reproductive development. Thereafter, partitioning to leaves and/or flowers or fruits above the ${ }^{14} \mathrm{C}$-treated leaf was related to leaf phyllotaxy $75 \%$ of the time.
\end{abstract}

The productivity of a plant depends on its genetic components, the environment in which it is grown, and the interaction between the two. Among many factors that limit productivity in any environment, $\mathrm{C}$ assimilation is one of the most important. If the assimilate supply becomes limited, flower initiation and development will suffer, especially in self-inductive polycarpic plants (Mor and Halevy, 1979). Assimilate partitioning and translocation direction can be acropetal or basipetal according to source-sink relationships. During the early developmental stages, expanded leaves of a nonstressed vegetative plant export most of their photoassimilates acropetally and the young leaves themselves constitute a strong sink. In a lemon branch or rose stem, the small $\mathrm{C}$ amount assimilated by the young leaves is retained (Mor and Halevy, 1979), while in apple and grape it is translocated acropetally (Hale and Weaver, 1962; Hansen, 1971), and in pecan and hibiscus it is moved bidirectionally (Adepipe, 1975; Davis and Sparks, 1974). With the appearance of flower buds, most of the leaves on a shoot have already changed from a sink to a source. In pecan, aspen, and rose, the young foliage, which is nearest to the flowers, supplies assimilates to the flowers and fruits, whereas the mature leaves usually supply the roots and branches (Davis and Sparks, 1974; Donnelly, 1974; Mor and Halevy, 1979). In many crops, the translocation direction is also associated with leaf orthostichy (Ho, 1988; Kappes and Flore, 1989; Larson, 1972).

A ring of bark can be removed from a stem (girdling) to stop the flow of assimilates through this zone until vascular connections are reestablished. Thus, girdling can be used to separate regions of growth or storage (sinks) from regions of assimilate production (sources). Several studies have indicated a decrease in net $\mathrm{CO}_{2}$ assimilation rate (A) after reducing sink activity (DeJong, 1986; Forney and Breen, 1985; Schaffer et al., 1987). Girdling has never been used before as a technique to study source-sink relationships in red raspberries.

Carbon budgeting has not received much attention in raspberries, although some work has been published on light interception (Braun et al., 1989; Palmer et al., 1987; Waister and Wright, 1989)

Received for publication 10 Mar. 1993. Accepted for publication 15 June 1993. We gratefully acknowledge financial assistance from Agriculture Canada to Jean-Pierre Privé while on educational leave as well as the Ontario Ministry of Agriculture and Food and the Ontario Berry Grower's Association. The cost of publishing this paper was defrayed in part by the payment of page charges. Under postal regulation, this paper must be hereby marked advertisement solely to indicate this fact.

${ }^{1}$ To whom reprint requests should be addressed. Present address: Atlantic Horticultural Research Centre, Agriculture Canada, Bouctouche, N.B., E0A 1G0, Canada. and dry-matter partitioning (Waister and Wright, 1989). In one study, selective removal of plant parts and radiotracer experiments revealed that the leaves at the lateral apex were a major source of assimilate during fruiting (Waister and Wright, 1989). The single leaves of fruiting laterals, fed with ${ }^{14} \mathrm{CO}_{2}$ at the onset of fruiting, translocated labelled $\mathrm{C}$ in the lateral with a heavy concentration in the young developing fruit.

The objectives of this study were to 1 ) investigate the influence of leaf removal and girdling on vegetative and reproductive cane development and 2) determine translocation patterns in the reproductive portion of the cane to better understand assimilate movement in the canes of primocane-fruiting $(\mathrm{PF})$ red raspberries.

\section{Materials and Methods}

Plant material. Three-year-old plants of 'Autumn Bliss', 'Heritage', and 'Redwing' PF red raspberries established in 20-liter pots with a 2 pine bark : 1 peat mixture (v/v) were used for the leafremoval and cane-girdling experiment, while only 'Heritage' was used in the ${ }^{14} \mathrm{C}$-translocation experiment. Set in a nursery area, plants were thinned to three canes per pot after the first flush of primocanes had emerged in the spring. Plants were watered as required and fertilized twice-weekly with 20N-20P-20K (200 $\mathrm{mg} \cdot$ liter $^{-1}$ ) through trickle irrigation.

Leaf-removal and cane-girdling experiment. A $3 \times 4 \times 2$ factorial experiment of cultivar, leaf-removal, and girdling treatments was performed as a randomized complete-block design with three replications. Leaf-removal and girdling treatments were done when the flower bud at the apex was visible. The four leafremoval treatments included 1) control with no leaf removal; 2) removal of all leaves; 3 ) leaf removal below the reproductive portion, hereafter referred to as the lower-leaf-removal treatment; and 4) removal of all leaves in the reproductive portion of the cane, hereafter referred to as the upper-leaf-removal treatment (Fig. 1). The third factor was the absence (control) or presence of a 5mm-wide strip removed of phloem, cambial tissue, and connected epidermis (girdle) placed $\approx 15$ nodes from the apex between the reproductive and the vegetative portion of the cane to prevent translocation between the two sections (Fig. 1). The exposed ring was covered with lanolin, monitored periodically for new growth, and scraped repeatedly until after harvests. At flowering, the bark slips easily and can be girdled with a budding knife. In a raspberry cane, the center of the stem is pith,i.e., a central core of unspecialized cells with very little structural support; therefore, each cane was 


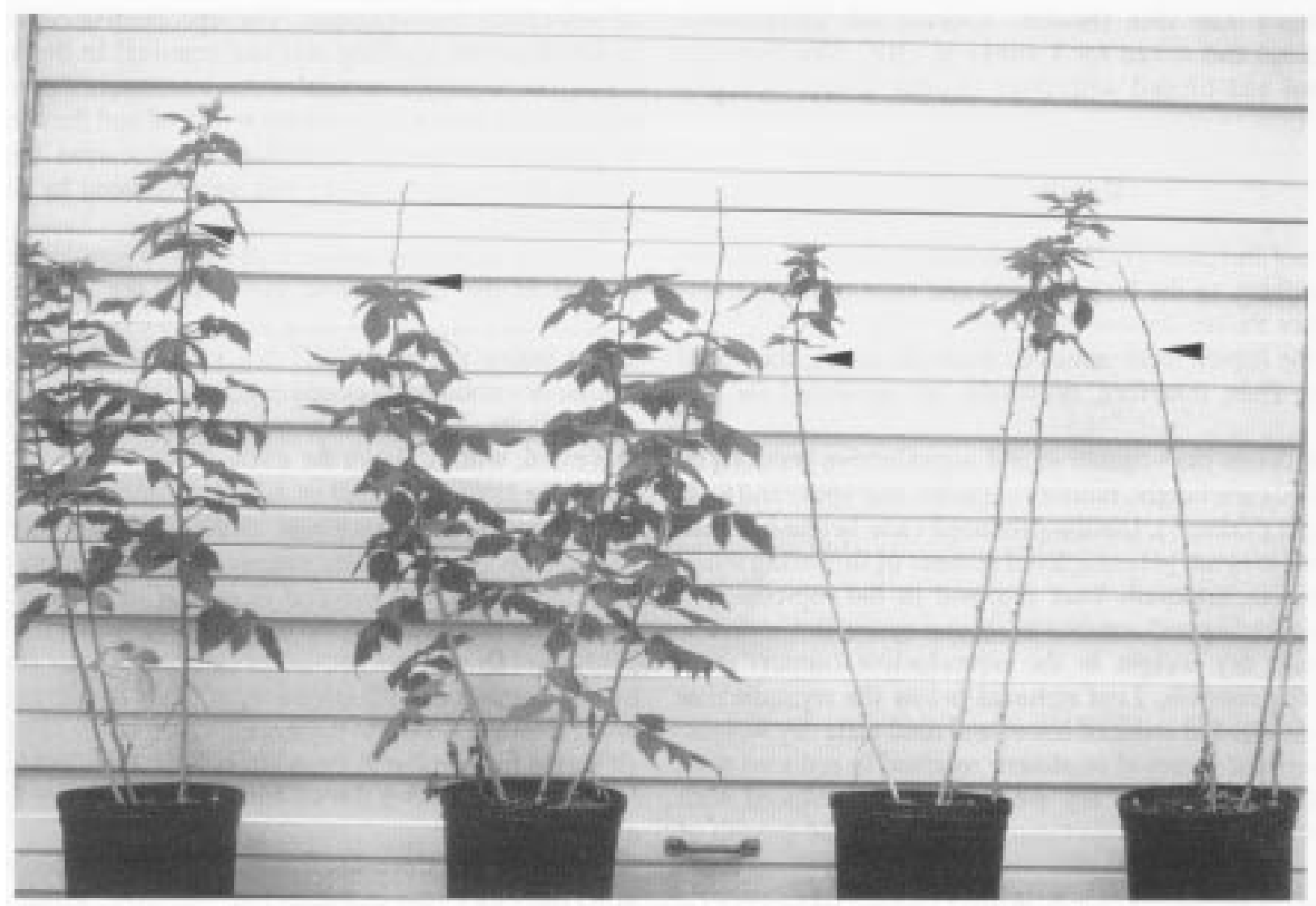

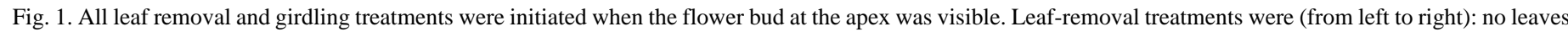

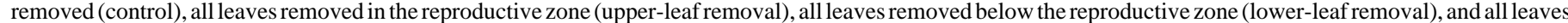
removed (all). The arrows indicate the approximate location of the girdle for half of the plants used in this experiment.

staked and tied to prevent breakage at the girdle.

Cane height and node number were measured from the basal bud to the apex and cane diameter was measured at the basal bud. The length of the fruiting section and the upper-cane dry weight were measured from the lowest fruiting lateral to the apex, and the remainder of the cane was used to calculate lower-cane dry weight. Dry weights were obtained after oven drying at 80C for 1 week. Berry number and weight were recorded daily from the date of first pick to the end of harvest.

To monitor differences in leaf A above and below the girdle, photosynthesis was measured with a portable photosynthesis system (model LI-6200; LI-COR, Lincoln, Neb.) equipped with a 0.25 -liter leaf chamber (total system gas volume of $390 \mathrm{ml}$ ). Airflow rates were adjusted manually to maintain uniform vaporpressure deficits in the chamber during leaf gas-exchange measurements $(\approx 0.9-1.3 \mathrm{kPa})$. Assimilation rate was calculated with a datalogger (model LI-6200; LI-COR) and appropriate software. Photosynthesis measurements were taken between 1000 and 1300 HR on fully expanded, healthy sun leaves. Environmental conditions during the experiment ranged from 16 to 33C (leaf temperature), 0.8 to $2.6 \mathrm{kPa}$ (vapor-pressure deficit), 0.32 to $0.34 \mathrm{mg}$. liter ${ }^{-1}\left(\mathrm{CO}_{2}\right)$, and 1200 to $2200 \mu \mathrm{mol} \cdot \mathrm{m}^{-2} \cdot \mathrm{s}^{-1}$ photosynthetically active radiation (PAR).

${ }^{14}$ Carbon translocation. Phyllotaxy was calculated from 15 plants according to the Allard method (1942), and eight plants were chosen to represent each of the early, intermediate, and late stages of reproductive development. Plants at the early stage of reproductive development were characterized by canes that only had flowers on the fruiting laterals. Intermediate-stage plants had fruit set at the apex and flowers at the other laterals, while the plants at the late developmental stage had both flowers and fruit throughout the reproductive zone. These plants were transferred from the nursery area to the greenhouse for exposure to ${ }^{14} \mathrm{C}$ the next day.

${ }^{14}$ Carbon was used to determine translocation patterns in the reproductive portion of the cane. In six of the eight plants, the seventh leaf from the apex was the ${ }^{14} \mathrm{C}$-treated leaf while, in the other two plants, leaves at nodes six and eight were treated. Assimilation rates were monitored on these ${ }^{14} \mathrm{C}$-treated leaves just before ${ }^{14} \mathrm{C}$ feeding and ranged from 4 to $9 \mu \mathrm{mol} \mathrm{CO} / \mathrm{C}^{2}$ per sec.

The direct application of carrier-free, high specific-activity $\left[{ }^{14} \mathrm{C}\right]$ urea to the foliar surface is performed conveniently and eliminates the need to enclose the tissue in a gas-tight feeding chamber. This method permits the incorporation of ${ }^{14} \mathrm{C}$ via the normal assimilatory route for $\mathrm{CO}_{2}$, which is produced as a product of urea catabolism (Pate and Farrington, 1981). Thus, endogenous $\mathrm{C}$ levels as well as assimilate-partitioning patterns should remain unaltered. The adaxial surface of each leaflet was supplied with a single 20-liter drop of carrier-free ${ }^{14} \mathrm{C}$-labeled urea, $[0.5 \mu \mathrm{Ci}(18.5$ $\mathrm{kBq}$ )] in $0.01 \%$ Triton $\mathrm{X}-114$ as a surfactant (Pate and Farrington, 1981). The prominent veins were avoided during this application. The ${ }^{14} \mathrm{C}$ feeding began at $1100 \mathrm{HR}$. After $24 \mathrm{~h}$, leaves and attached flowering and/or fruiting laterals were removed from the cane using a scalpel and fixed to $36 \times 43-\mathrm{cm}$ sheets of white paper with glue. The bilateral phyllotaxic arrangement of the leaves and accompanying flowers and/or fruit of each of the raspberry canes was recorded when the plant parts were mounted. Specimens were placed between two sheets of blotting paper, two sheets of corrugated cardboard, and two $40 \times 50-\mathrm{cm}$ sheets of 1 -cm-thick ply- 
wood, lightly pressed, and then set to dry in a forced-draught oven at $80 \mathrm{C}$ for $3.5 \mathrm{~h}$. Subsequently, they were pressed at $6.9 \mathrm{MPa}$ and cooled at room temperature for $6 \mathrm{~h}$. The dry, pressed samples were placed in contact with film (Kodak, X-Omat AR Electromed, Toronto, Ontario) and stored for 3 weeks at $-30 \mathrm{C}$. The film was then developed and treated with fixer (Kodak X-ray, Toronto, Ontario).

\section{Results}

Leaf-removal and cane-girdling experiment. All three cultivars responded similarly to the leaf-removal and cane-girdling treatments; therefore, the results were averaged over the three cultivars. When all of the leaves were removed from the canes, they died before bearing fruit; therefore, no results are presented for this treatment.

Girdling between the vegetative and reproductive portions of the cane reduced cane height, number of nodes, and upper and total cane dry weight (Table 1). Girdling reduced cane height because cane elongation was not yet completed at onset of flowering when the treatment was imposed. Leaf removal in the reproductive portion of the cane (upper) resulted in shorter canes, fewer nodes, and lower plant dry weight in the reproductive (upper) zone compared to the controls. Leaf removal below the reproductive zone (lower) resulted in reduced lower and total cane dry weight. Only the lower-leaf-removal treatment resulted in reduced total cane dry weight. Total cane dry weight was not reduced with upper-leaf removal because this treatment induced the growth of

Table 1. Girdling, leaf removal, and girdling $\times$ leaf-removal interactions on the vegetative components averaged over three primocane-fruiting red raspberry cultivars.

\begin{tabular}{|c|c|c|c|c|c|c|}
\hline \multirow[b]{2}{*}{ Treatment $^{\mathrm{y}}$} & \multicolumn{2}{|c|}{ Cane } & \multirow{2}{*}{$\begin{array}{c}\text { Node } \\
\text { no. } \\
\text { (cane) }\end{array}$} & \multirow{2}{*}{$\begin{array}{l}\text { Upper } \\
\text { cane } \\
\text { dry } \mathrm{wt}^{\mathrm{z}} \\
(\mathrm{g})\end{array}$} & \multirow{2}{*}{$\begin{array}{l}\text { Lower } \\
\text { cane } \\
\text { dry } \mathrm{wt}^{\mathrm{z}} \\
\text { (g) }\end{array}$} & \multirow{2}{*}{$\begin{array}{l}\text { Total } \\
\text { cane } \\
\text { dry wt } \\
\quad(\mathrm{g})\end{array}$} \\
\hline & $\begin{array}{l}\mathrm{Ht} \\
(\mathrm{cm})\end{array}$ & $\begin{array}{c}\text { Diam } \\
(\mathrm{cm})\end{array}$ & & & & \\
\hline \multicolumn{7}{|c|}{ Girdling $^{x}$} \\
\hline Nongirdled & $103 \mathrm{a}^{\mathrm{v}}$ & 1.1 & $34 \mathrm{a}$ & $12 \mathrm{a}$ & 30 & $42 \mathrm{a}$ \\
\hline Girdled & $95 \mathrm{~b}$ & 1.0 & $31 \mathrm{~b}$ & $10 \mathrm{~b}$ & 31 & $41 \mathrm{a}$ \\
\hline \multicolumn{7}{|c|}{ Leaf removal ${ }^{w}$} \\
\hline Control & $104 \mathrm{a}$ & 1.1 & $33 \mathrm{a}$ & $14 \mathrm{a}$ & 32 & $46 \mathrm{a}$ \\
\hline Lower & $102 \mathrm{a}$ & 1.0 & $34 \mathrm{a}$ & $15 \mathrm{a}$ & 14 & $29 \mathrm{~b}$ \\
\hline Upper & $91 \mathrm{~b}$ & 1.1 & $31 \mathrm{~b}$ & $4 \mathrm{~b}$ & 45 & $49 \mathrm{a}$ \\
\hline \multicolumn{7}{|c|}{ Significance } \\
\hline
\end{tabular}

Girdle $\times$

$\begin{array}{lllllll}\text { leaf removal NS } & 0.02 & \text { NS } & \text { NS } & 0.07 & \text { NS }\end{array}$

${ }^{\mathrm{z}}$ Upper-cane dry weight includes leaves, canes, and fruiting laterals (if present) in the reproductive top portion of the cane. Lower-cane dry weight includes leaves, canes, and vegetative laterals (if present) below the reproductive zone.

${ }^{\mathrm{y}}$ Leaf-removal and girdling treatments were done when the flower bud at the apex was visible. Vegetative components were measured after harvests, i.e., 2 to 3 months after treatment.

${ }^{\mathrm{x}}$ Girdling treatments were done between the reproductive and the vegetative zone.

${ }^{w}$ Leaf-removal treatments were Control, no leaf removal; Lower, leaf removal below the reproductive zone; and Upper, leaf removal in the reproductive portion of the cane.

${ }^{\mathrm{v}}$ Main effect means separated for girdling and leaf-removal treatments by LSD at $P \leq 0.05$. Mean separation was not indicated when a girdle $\times$ leafremoval interaction was significant.

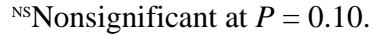

vegetative laterals below the reproductive zone, which helped to compensate for the loss of dry weight by the upper portion.

Significant girdling $\times$ leaf-removal interactions were found for all reproductive components. The reproductive components failed to develop with girdling and leaf removal in the upper portion, hence, the negligible results of this treatment (Table 2). When the leaves in the lower section were removed and the cane was girdled to prevent downward assimilate translocation from the upper leaves, berry number and yield were reduced by $36 \%$ and $42 \%$, respectively.

As long as flowers and/or fruit were present in the reproductive portion of the cane above the girdle, the leaves in this zone maintained a higher $\mathrm{A}\left(7.2 \pm 1.5 \mu \mathrm{mol} \mathrm{CO} / \mathrm{m}^{2}\right.$ per sec $)$ than the leaves below the girdle $\left(4.7 \pm 2.5 \mu \mathrm{mol} \mathrm{CO} / \mathrm{m}^{2}\right.$ per sec) under similar environmental conditions, i.e., $\mathrm{PAR}, \mathrm{CO}_{2}$, and vapor pressure deficits. The situation was reversed once all the fruit was harvested, with A above the girdle dropping to $48 \%$ of the leaves below the girdle ( $3.2 \pm 1.9 \mathrm{vs} .6 .7 \pm 2.0 \mu \mathrm{mol} \mathrm{CO} / \mathrm{m}^{2}$ per sec). Leaf A on control plants without girdles did not exhibit the same response as on the girdled canes. Only once during the 2-month experimental period was leaf A greater in the reproductive zone than in the leaves below the reproductive zone $(10.0 \pm 0.5 \mathrm{vs} .8 .5$ $\pm 0.5 \mu \mathrm{mol} \mathrm{CO} / \mathrm{m}^{2}$ per sec) when compared under similar environmental conditions. Otherwise, upper leaf A was either similar or lower than the leaves in the lower region of the cane. Conversely, all leaves had similar A even after all the fruit had been harvested (upper leaves $=6.3 \pm 0.6$ vs. lower leaves $=6.2 \pm 0.7 \mu \mathrm{mol} \mathrm{CO}_{2} /$ $\mathrm{m}^{2}$ per sec).

${ }^{14}$ Carbon translocation. Leaf phyllotaxy was counter-clockwise in 10 and clockwise in five of the 'Heritage' plants sampled. The phyllotaxic arrangement was more variable at the lower and upper sections of the cane than in the mid-section. 'Heritage' plants may represent either a $1 / 2,1 / 3,2 / 5$, or $3 / 8$ leaf arrangement, with the $3 /$ 8 arrangement as the most common leaf arrangement in the cane's mid-section. In the reproductive section, a progression from $1 / 3$ to $1 / 2$ was most common.

When ${ }^{14} \mathrm{C}$ translocation was studied in the reproductive portion of the cane, the fruiting lateral closest to the ${ }^{14} \mathrm{C}$-treated leaf was always a major sink for labelled assimilates, regardless of repro-

Table 2. Influence of girdling $\times$ leaf-removal interactions on the reproductive components averaged over three primocane-fruiting red raspberry cultivars.

\begin{tabular}{|c|c|c|c|c|c|}
\hline \multicolumn{2}{|c|}{ Treatment $^{2}$} & \multirow{2}{*}{$\begin{array}{l}\text { Length of } \\
\text { fruiting } \\
\text { section } \\
(\mathrm{cm})\end{array}$} & \multirow{2}{*}{$\begin{array}{c}\text { Berry } \\
\text { no. } \\
\text { (cane) }\end{array}$} & \multirow{2}{*}{$\begin{array}{c}\text { Berry } \\
\text { wt } \\
(\mathrm{g})\end{array}$} & \multirow[b]{2}{*}{$\begin{array}{c}\text { Yield } \\
\text { (g/cane) }\end{array}$} \\
\hline Girdling $^{\mathrm{y}}$ & $\begin{array}{c}\text { Leaf } \\
\text { removal }^{\mathrm{x}}\end{array}$ & & & & \\
\hline \multirow[t]{3}{*}{ Control } & Control & $33 a^{w}$ & $93 \mathrm{a}$ & $1.8 \mathrm{a}$ & $170 \mathrm{a}$ \\
\hline & Lower & $31 \mathrm{a}$ & $91 \mathrm{a}$ & $1.9 \mathrm{a}$ & $175 \mathrm{a}$ \\
\hline & Upper & $25 \mathrm{~b}$ & $102 \mathrm{a}$ & $1.6 \mathrm{~b}$ & $164 \mathrm{a}$ \\
\hline \multirow[t]{3}{*}{ Girdled } & Control & $33 a$ & $88 \mathrm{a}$ & $2.0 \mathrm{a}$ & $170 \mathrm{a}$ \\
\hline & Lower & $31 \mathrm{a}$ & $56 \mathrm{~b}$ & $1.7 \mathrm{ab}$ & $99 \mathrm{~b}$ \\
\hline & Upper & $5 \mathrm{~b}$ & $2 c$ & $1.0 \mathrm{c}$ & $3 \mathrm{~b}$ \\
\hline
\end{tabular}

${ }^{\mathrm{z}}$ Leaf-removal and girdling treatments were done when the flower bud at the apex was visible.

${ }^{\mathrm{y}}$ Girdling treatments were done between the reproductive and the vegetative zone.

${ }^{x}$ Leaf-removal treatments were: Control, no leaf removal; Lower, leaf removal below the reproductive zone; and Upper, leaf removal in the reproductive portion of the cane.

${ }^{\mathrm{w}}$ Girdling $\times$ leaf-removal interactions were significant for all reproductive components analyzed. Means separated in columns by LSD at $P \leq 0.05$. 
ductive development (Fig. 2 A and B). Thereafter, translocation to leaves, flowers, or fruits above the ${ }^{14} \mathrm{C}$-treated leaf was related to leaf phyllotaxy in six of the eight canes. For example, translocation from node seven followed the leaf phyllotaxy of $1 / 3$ and, as a result, node four was a stronger sink for ${ }^{14} \mathrm{C}$ than nodes five and six (Fig. $2 \mathrm{~A}$ and B). Thereafter, translocation changed with changing phyllotaxy. A similar pattern in translocation was also observed when leaves at nodes six and eight were labelled with ${ }^{14} \mathrm{C}$ (autoradiographs not shown).

The priority of partitioning also depended on the stage of plant development. When only flowers were present on the upper cane, translocation from the source leaf was both to the young developing leaves and to the inflorescences (Fig. 2A). However, when both young developing leaves and developing fruit were present on the laterals, more of the ${ }^{14} \mathrm{C}$ was translocated to the fruit than to the young leaves (Fig. 2B).
Although A capacity was lower in two of the eight ${ }^{14} \mathrm{C}$-treated leaves, translocation patterns were similar to the leaves with higher A rates (autoradiographs not shown).

\section{Discussion}

Crop productivity is a function of radiation interception, photosynthetic capacity, efficiency of conversion to dry matter, the partitioning of dry matter to the usable organs, and the water content of these organs (Ho, 1988). Carbohydrate partitioning and translocation were studied to understand the controls on growth and productivity in PF red raspberries.

In our study, the flowering or fruiting lateral closest to the ${ }^{14} \mathrm{C}$-treated leaf was always the largest sink. Autoradiography also demonstrated that assimilate translocation was related to leaf phyllotaxy $75 \%$ of the time. In another study, ${ }^{14} \mathrm{CO}_{2}$ fed to

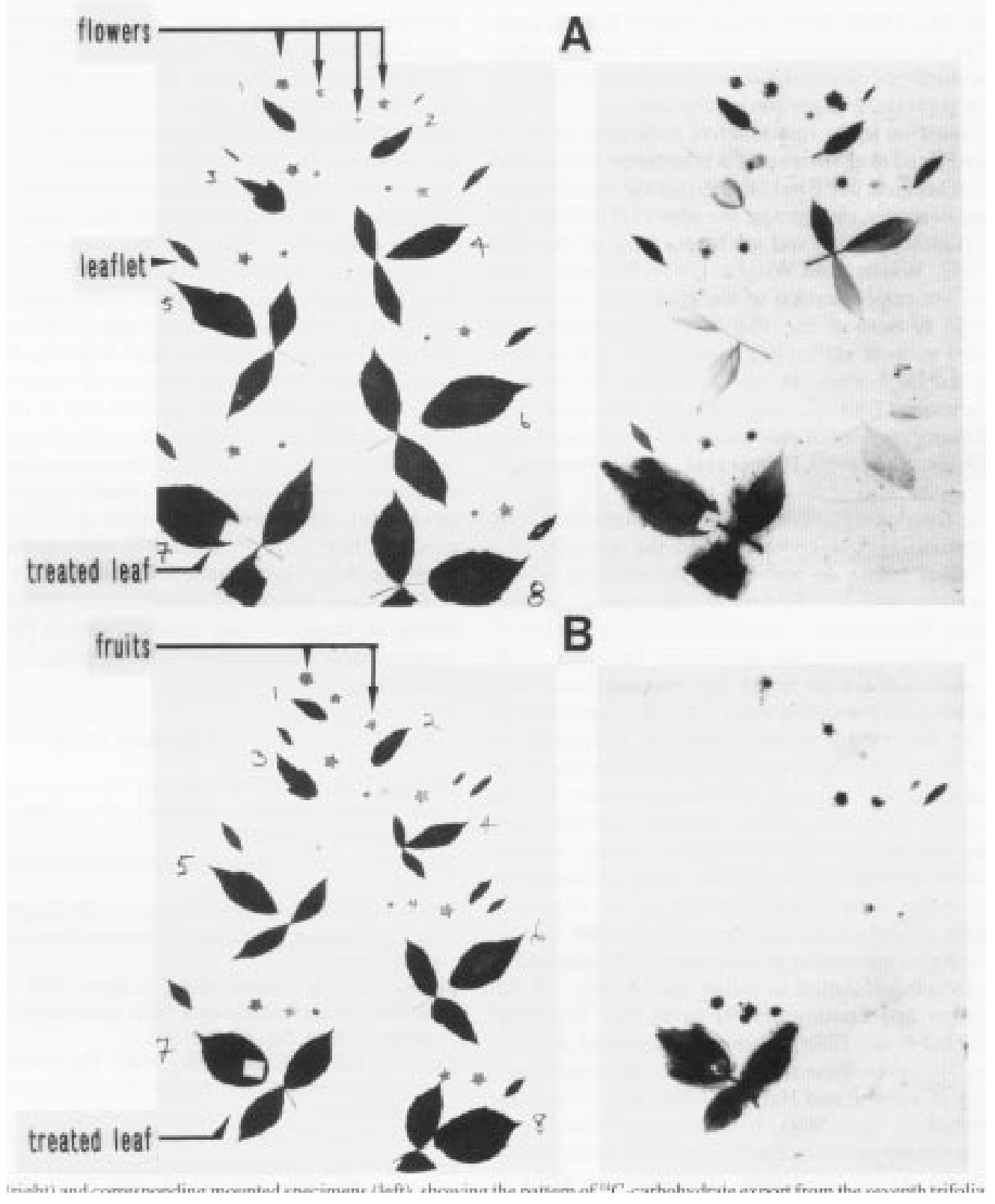

Fig. 2. Autoradiographs (right) and corresponding mounted specimens (left), showing the pattern of ${ }^{14} \mathrm{C}$-carbohydrate export from the seventh trifoliate leaf of 'Heritage' at anthesis $(\mathbf{A})$ and at fruit set $(\mathbf{B})$. Specimens were harvested $24 \mathrm{~h}$ after treatment. Note that the translocation of photosynthate from the ${ }^{14} \mathrm{C}$ treated-leaf at node 7 followed the leaf phyllotaxy of $1 / 3$ to node 4 in both A and B. At anthesis (A), translocation from the source leaf was both to the leaves and the inflorescences, while at fruit set (B) it was translocated mostly to the fruit $(\mathbf{B})$. 
single leaves of summer-bearing red raspberries at the onset of fruiting was also translocated to the nearest fruiting lateral (Waister and Wright, 1989). These studies suggest that for both PF and summer-bearing red raspberries, the leaves nearest the fruiting lateral are an important source of assimilates for those sinks. The lack of correlation between leaf $\mathrm{A}$ and crop yield has been implicitly stated in much of the literature on both fruit and cereal crops and has been reviewed by Elmore (1980). The problem in many studies is the lack of relationship between individual leaf A taken under optimum conditions and the subsequent crop yield. In our study, leaf A above the girdle was higher than the leaves below the girdle when sinks were present. Concurrently, the autoradiographs demonstrated that destination of assimilates from the source leaf varied according to the stage of plant development. At anthesis, translocation from the labelled source leaf was to both the leaves and inflorescences, but was only to the fruit following fruit set. Similar results have been reported in grape (Hale and Weaver, 1962) and tomato (Ho, 1988). These results suggest that the large trifoliate leaves in the reproductive portion of the cane strongly influence crop productivity via translocation of its photoassimilates to the sinks in the reproductive portion of the cane.

Radiation interception in the reproductive zone may not be as major a concern in PF red raspberries as it is in summer-bearing red raspberries. This is because in $\mathrm{PF}$ red raspberries the reproductive portion of the cane occupies, on average, the upper $1 / 2$ to $1 / 3$ of the cane (Pritts and Handley, 1989) and intercepts most of the light (Palmer et al., 1987; Waister and Wright, 1989). We also found that the leaves in the upper portion of the cane were also very important for yield as most of the photoassimilates from these leaves are directed to their subtending fruits. This differs from summer-bearing red raspberries, in which competition for light between primocanes and floricanes significantly influences crop productivity and major portions of the canopy and individual canes may be shaded (Braun et al., 1989; Palmer et al., 1987; Waister and Wright, 1989).

The import rate for a specific sink organ can be altered either by increasing its sink strength or by decreasing the strength of a competing sink (Ho, 1988). In our study, the strength of the competing sinks to the fruit, i.e., the leaves, was reduced by leafremoval treatments. Yield was not significantly reduced by any of the leaf-removal treatments in the nongirdled canes, a result suggesting that assimilates were being translocated from other sections of the plant. Compensation was clearly demonstrated by the comparison of the control to the nongirdled lower-leaf-removal treatment. Even when $>2 / 3$ of the leaf area was removed, yield was not significantly reduced. This suggests that PF red raspberries are more sink- than source-limited. Compensatory yield response has also been reported in summer-bearing cultivars following bud removal (Waister and Wright, 1989). Although not measured in our study, increased A capacity of the remaining leaves on the canes is likely a compensatory mechanism responsible for maintaining yields similar to the controls. A reduction in leaf area from partial defoliation in either the 'Amity' PF red raspberry (Cameron and Hartley, 1989) or in the 'Redchief' strawberry (Kerkhoff et al., 1988) resulted in increased A in the remaining leaves. However, these rates were only observed over 2 days for raspberry (Cameron and Hartley, 1989) and 15 days for strawberry (Kerkhoff et al., 1988). It is unknown whether increased A could be maintained over 2 to 3 months, especially when leaf area is known to be positively correlated to yield in summer-bearing red raspberries (Khanmai and Brown, 1939; Waister and Wright, 1989). Whatever the mechanism, PF red raspberries have the ability to maintain yield potential by compen- sating for the loss of a substantial proportion of leaf area, even over 2 to 3 months. However, our study did not address the potential carbohydrate translocation to and from the root and its contribution to the source-sink balance of the plant. In summer-bearing red raspberries, carbohydrates are known to move up and down firstyear canes (Engard, 1939), and root reserves are renewed after fruiting in the fall (Jennings and Carmichael, 1975). It is also known that a lowering of leaf-area index by primocane suppression can result in a decline of raspberry yield after several seasons (Lawson and Wiseman, 1983). For these reasons, the effect of leaf removal on translocation patterns of photoassimilates to all plant parts should be studied.

Girdling interfered with the source-sink relationships in the PF raspberry canes by obstructing assimilate translocation to and from the upper and lower portions of the cane. Thus, no yields were obtained when the upper leaves were removed and a girdle prevented the photoassimilate translocation from the lower leaves to the reproductive sinks in the cane's upper portion. In the reversed situation, when all the leaves below the girdle were removed, yields were reduced by $58 \%$. It is likely that, over the 2- to 3-month experimental period, the lack of downward movement of photoassimilates from the upper source leaves to the roots gradually depleted the carbohydrates in these roots. At the end of the experiment, a visual inspection revealed discolored roots, a result suggesting that yield reduction may have been partly due to negative secondary effects of root necrosis.

Although A was lower at the end of the season, after the fruit had been harvested, leaves along the entire cane were still photosynthetically active. In contrast, when no fruit was present in the upper portion of the girdled plants, leaf A during this same period was much reduced. The results from our girdling experiments confirm that sinks helped maintain optimal leaf A (Monselise and Lenz, 1980; Schaffer et al., 1987). Assimilate translocation from the upper leaves in the nongirdled plants must have been downward to the roots, where sink activity is usually quite strong relative to the other plant components at this time of year (Atkinson, 1973). In contrast, there were no accessible sinks in the girdled plants and, therefore, little photosynthetic capacity.

Continued studies of translocation patterns in whole plants during all stages of cane development in PF red raspberries are required to further our understanding of the carbohydrate economy of the cane.

\section{Literature Cited}

Adepipe, N.O. 1975. Time course of ${ }^{14} \mathrm{C}$-sucrose translocation by successive leaves of Hibiscus esculentus L. (Okra). Biochemie Physiologie der Pflanzen 167:419-427.

Allard, H.A. 1942. Some aspects of the phyllotaxy of tobacco. J. Agr. Res. 64:49-55.

Atkinson, D. 1973. Seasonal changes in the length of white unsuberized root on raspberry plants grown under irrigated conditions. J. Hort. Sci. 48:413-419.

Braun, J.W., J.K.L. Garth, and C.A. Brun. 1989. Distribution of foliage and fruit in association with light microclimate in the red raspberry canopy. J. Hort. Sci. 64:565-572.

Cameron, J.C. and C.A. Hartley. 1989. The influence of leaf : fruit ratio on gas exchange characteristics of red raspberry leaves. Acta Hort. 262:255-258.

Davis, J.T. and D. Sparks. 1974. Assimilation and translocation patterns of carbon-14 in the shoot of fruiting pecan trees Carya illonensis Koch. J. Amer. Soc. Hort. Sci. 99:468-480.

DeJong, T.M. 1986. Fruit effects on photosynthesis in Prunus persica. Physiol. Plant. 66:149-153.

Donnelly, J.R. 1974. Seasonal changes in photosynthate transport with 
elongating shoots of Populus grandidentata. Can. J. Bot. 52:25472559.

Elmore, C.D. 1980. The paradox of no correlation between leaf photosynthetic rates and crop yields, p. 155-167. In: J.D. Hesketh and J.W. Jones (eds.). Predicting photosynthesis for ecosystem models. CRC Press, Boca Raton, Fla.

Engard, C.J. 1939. Translocation of carbohydrates in the Cuthbert raspberry. Bot. Gaz. 100:439-464.

Forney, C.F. and P.J. Breen. 1985. Dry matter partitioning and assimilation in fruiting and deblossomed strawberry. J. Amer. Soc. Hort. Sci. 110:181-185.

Hale, C.R. and R.J. Weaver. 1962. The effect of developmental stage on direction of translocation of photosynthate in Vitis vinifera. Hilgardia 33:89-131.

Hansen, P. 1971. ${ }^{14} \mathrm{C}$-studies on apple trees. VII. The early seasonal growth in leaves, flowers and shoots as dependent upon current photosynthates and existing reserves. Physiol. Plant. 25:469-473.

Ho, L.C. 1988. Metabolism and compartmentation of imported sugars in sink organs in relation to sink strength. Annu. Rev. Plant Physiol. 39:355-378.

Jennings, D.L. and E. Carmichael. 1975. Some physiological changes occurring in overwintering raspberry plants in Scotland. Hort. Res. 14:103-108.

Kappes, E.M. and J.A. Flore. 1989. Phyllotaxy and stage of leaf and fruit development influence initiation and direction of carbohydrate export from sour cherry leaves. J. Amer. Soc. Hort. Sci. 114:642-648.

Kerkhoff, K.L., J.M. Williams, and J.A. Barden. 1988. Net photosynthetic rate and growth of strawberry after partial defoliation. HortScience 23:1086.
Khanmai, M.A. and W.S. Brown. 1939. Correlations between leaf area and leaf weight and between leaf weight and fruit production of red raspberries. Proc. Amer. Soc. Hort. Sci. 37:589-592.

Larson, P.R. 1972. Interpretation of radioisotope translocation patterns in forest trees. Isotopes and radiation in soil-plant relationships including forestry. Intl. Atomic Energy Agency, Vienna, Austria, p. 277-288.

Lawson, H.M. and J.S. Wiseman. 1983. Techniques for the control of cane vigour in red raspberry in Scotland: effects of timing and frequency of cane removal treatments on growth and yield in cv. Glen Cova. J. Hort. Sci. 58:247-260.

Monselise, S.P. and F. Lenz. 1980. Effects of fruit load on stomatal resistance, specific leaf weight, and water content of apple leaves. Gartenbauwes 45:188-191.

Mor,Y. and A. Halevy. 1979. Translocation of ${ }^{14} \mathrm{C}$-assimilates in roses. I. The effect of the age of the shoot and the location of the source leaf. Physiologia Plantarum 45:177-182.

Palmer, J.W., J.E. Jackson, and D.C. Ferree. 1987. Light interception and distribution in horizontal and vertical canopies of red raspberries. J. Hort. Sci. 62:493-499.

Pate, J.S. and P. Farrington. 1981. Fruit set in Lupinus angustifolius cv. Unicrop: II. Assimilation flow during flowering and early fruiting. Austral. J. Plant Physiol. 8:307-318.

Pritts, M. and D. Handley. 1989. Bramble production guide. NRAES-35, Northeast Regulat. Agr. Eng. Serv. Coop. Ext., Ithaca, N.Y.

Schaffer, B., L. Ramos, and S.P. Lara. 1987. Effect of fruit removal on net gas exchange of avocado leaves. HortScience 22:925-927.

Waister, P.D. and C.J. Wright. 1989. Dry matter partitioning in cane fruits, p. 51-61. In: C.J. Wright (ed.). Manipulation of fruiting. Butterworth \& Co. Ltd., London. 